\title{
Analyzing the Impact of External Debt on Capital Formation in Nigeria: An Autoregressive Distributed Lag Approach
}

\author{
Muhammad Mustapha Abdullahi \\ School of Economics Finance and Banking, Universti Utara Malaysia
}

Sallahuddin B Hassan

Department of Economics and Agribusiness, School of Economics, Finance and Banking, UUM COB Universiti Utara Malaysia, 06010 Sintok, Kedah, Malaysia.Email: din636@uum.edu.my

Nor Aznin Bt Abu Bakar

School of Economics Finance and Banking, Universti Utara Malaysia

Doi:10.5901/mjss.2016.v7n1p173

\begin{abstract}
This study aimed at examining the impact of external debt to the growth and development of capital formation in Nigeria. Time series data was utilized for a period from 1980 to 2013, employing the Autoregressive Distributed Lag (ARDL) modelling. The result of stationarity tests reported a mixed integration at both I(0) and I(1) hence warranting the use of the ARDL. The ARDL estimation also showed the presence of long run relationship amongst the variables. It was also proved that the variables were independently related in the long run. The impact of external debt on capital formation has been established to be negative and statistically significant while savings came out as the only variable with a bidirectional causal relationship amongst the variables. Interest rate was found to be statistically significant even though weak. The other variables were found to be of unidirectional casual effects. Short-run dynamics of the relationship between the variables have also been examined using $A R D L$ error correction modelling. It was established that the disequilibrium in the previous period will be adjusted within the current period by 68 percent showing a speedy adjustment rate. The coefficient of ECM term has the expected sign and significant at one percent. Going by these findings therefore savings should be giving priority and encouraged internally in order to boost the speed of the growth of capital formation in the economy.
\end{abstract}

Keywords: External Debts, Capital Formation, ARDL, Nigeria

\section{Introduction}

Economies of the third world are generally characterized by low and weak growth rates due to their inherent nature of under savings, which retards them from providing financial support for investment in both private and public sectors. Savings and investment are therefore, two major macroeconomics variables that support and sustains economic growth (Hunt, 2007). Linked to this is also the fact that economic growth cannot be sustained and maintained unless the level and the structure of capital reaches a certain threshold (Sachs, 2002). Unfortunately however domestic savings is not enough to sustain the expected capital formation that fuels economic growth hence the resort to foreign borrowing (Chenery \& Strout, 1966).

Ajayi and Khan (2000) propounded that the most important consideration in contracting external debt is a simple and direct one; signing up for debt from abroad only when investments can generate higher returns than the cost of funds. The borrowing nations would be enhancing their productivity and national output through investments facilitated by borrowed funds as explained by the dual-gap theory. The function of foreign capital is that it assists third world economies in investing much higher than they might have saved internally; which is a sort of necessity resulting from deficits in domestic savings (McKinnon, 1964).

It is justified therefore to say that, the growth and development of the Nigerian economy cannot be fully understood without a closer look at the contribution of external debt as its affects capital formation. This is with the understanding that capital formation and its source of funding have been recognized as important factors that determine the smooth economic growth and development of all nations hence goes a long way in justifying this study. 
There are many studies on the effects of external debt on investment but quite few between external debt and capital formation as it affects economics growth. The results and findings of these studies were mostly inconclusive and sometimes mixed. While some have come up with negative findings, many have concluded on a positive note, with quite a few reporting on both. The area of study was also more often than not on a general region of sub Saharan Africa. This study has used robust ARDL approach for examining the relationship between foreign borrowing and capital formation in particular and as its affects Nigeria as an entity.

Apart from conflicting and inconclusive results, the analytical tools employed were weak and non-rigorous. These discrepancies have added to the existence of a gap in the literature and thus necessitating a more efficient, wide-ranging, more concentrated and specific study of the relationship between external borrowing and capital formation in particular. The study will therefore be among the few, if any to focus specifically on how external debt and capital formation are related in Nigeria.

Essentially outcome of the study will guide policy makers in determining the extent to which external debt augments the shortfall in the capital requirement of the country. This work is divided into four sections. While background to the study area is given in Section 1, Section 2 discusses macro facts of external debt and capital formation, Section 3 examines the literature at theoretical, conceptual and empirical levels to form a solid foundation for our analysis. Section 4 covers the methodology adopted for the work, Section 5 deals with the empirical analysis and Section 6 summarizes and concludes on the results and findings.

\section{Macro Facts on External Debt and Capital Formation}

The history of foreign debt in Nigeria started barely half a century back with the contracting of $\$ 28$ million used in financing the first rail line project in the country. From 1970, the external debt needs were reasonable and within limit up to when the world crude oil market suffered a serious fall in price in 1978. This naturally exerted a burden on the government, that warranted the signing of more foreign loans in order to finance the increasing deficits in its budgets (Aliyu \& Usman, 2013, Sulaiman \& Azeez, 2012; Omotoye, Sharma, Ngassam, \& Eseonu, 2006). The trend continued into the 1980s when Nigeria's foreign debt drastically escalated due to the falling oil exports coupled with the discouragement to invest contributing to the relatively low economic performance of the economy.

With the worsening economic situation and adoption of Structural Adjustment Program (SAP) in 1986 brought about an increasing need for reforms, especially in terms of increasing imports at the expense of dwindling exports, declining growth, increasing unemployment, worsening inflation, deterioration in balance of payments, debilitating debt crunch and increasing unsustainable budget deficits. The major policy thrust of the SAP was redirection from inward-looking import substitution strategy to outward looking export promotion strategy and the final policy instrument was the exchange rate as a result of which debt stock grew from $\$ 4.6$ billion in 1980 to $\$ 18.6$ billion in 1986, $\$ 29.70$ billion in 1988 and $\$ 32.9$ billion at the end of 1990; resultant effects of mostly devaluation and deregulation (see Figure 1).

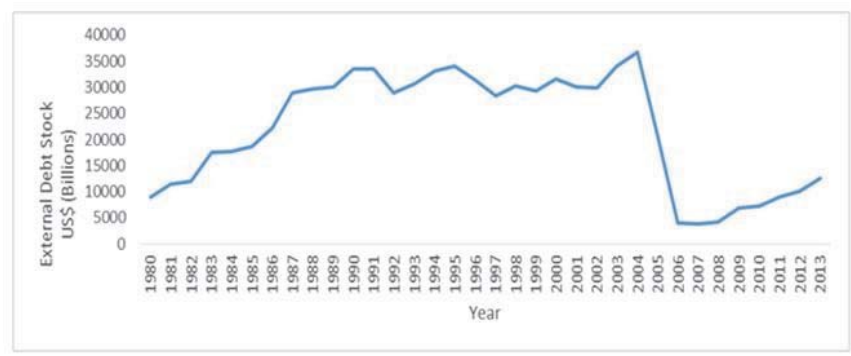

Figure 1: Trend of Total External Debt Stock, 1980 - 2013

The country's external debt stock composition at its peak by 2004 was such that $\$ 30.8$ billion from the total outstanding debt was from the 14 member Paris Club and $\$ 2.8$ billion from the London Club while $\$ 2.2$ billion came from the multilateral financial institutions (Ajab \& Audu, 2006). This composition which was grossly skewed in favor of the Paris Club of creditors did not help matters, especially in terms of pricing and the overall contract terms; and subsequent debt relief negotiations. This position is shown in Table 1. 
Table 1: Composition of Total External Debt Prior to Debt Relief in \$ (Billion)

\begin{tabular}{lccccc}
\hline Creditors & 1985 & 1991 & 1992 & 1998 & $\mathbf{2 0 0 4}$ \\
\hline Paris Club & 7.8 & 17.8 & 16.4 & 20.8 & 30.8 \\
Non-Paris & 1.9 & 1.4 & 1.2 & 0.1 & 0.0 \\
Commercial & 7.8 & 10.5 & 5.4 & 3.6 & 2.2 \\
Multi-lateral & 1.3 & 4.0 & 4.5 & 4.2 & 2.8 \\
Total & 18.9 & 33.7 & 27.6 & 28.8 & 35.9 \\
\hline
\end{tabular}

Source: Debt Management Office (DMO), Nigeria, 2013.

With total exist from the Paris Club in 2006; the external debt stock figure has significantly gone down to $\$ 3.5$ billion and $\$ 3.4$ billion in 2006 and 2007, respectively as indicated by Figure 2. The debt figure however has been on a steady increase since then; $\$ 3.7$ billion in 2008, $\$ 3.9$ billion in 2009, $\$ 4.5$ billion in 2010, $\$ 5.7$ billion in 2011, $\$ 6.5$ billion in 2012 and $\$ 9.0$ billion in 2013 (DMO, 2014). This pattern gives a clear sign of the debt stock position getting back to the previous bad debt sustainability level within a short time frame.

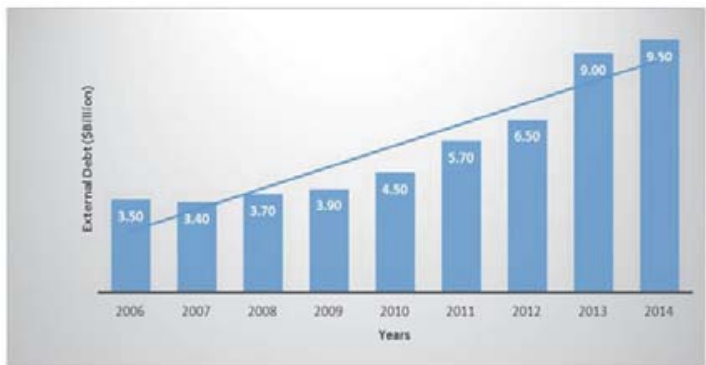

Figure 2: Post Debt Relief External Debt Accumulation Pattern

Theories and empirical evidence abound to prove that no meaningful economic growth can take place and be sustained without countries and economies surviving capital formation at a less than GDP growth rate. It is also well known that the ratio of capital formation to GDP that is below 27 percent cannot sustain meaningful economic development (HernándezCatá, 2000). It has been documented that gross capital formation ratio to GDP in SSA countries that have witnessed slowing growth rates in the 1990s averaged below 17 percent, while advanced economies recorded over and above 27 percent. The SSA countries ratio falls far below the acceptable minimum ratio (Gillis, Perkins, Roemer \& Snodgrass, 1987).

Records have shown that between 1970 and 2013 Nigeria's capital formation reached a maximum of $\$ 29.8$ billion, 9.9 times its 1970 position of $\$ 3$ billion. The average annual increase of capital formation of Nigeria is $\$ 0.64$ billion or 21.3 percent while the least capital formation of Nigeria was in 1995 (\$2.1 billion). Retrogressively however from Figure 3, it can be observed that apart from early 80s when the capital formation to GDP ratio reached a peak of 29 percent it has persistently remained far below 27 percent threshold requirement to as low as 10.5 percent in 2013.

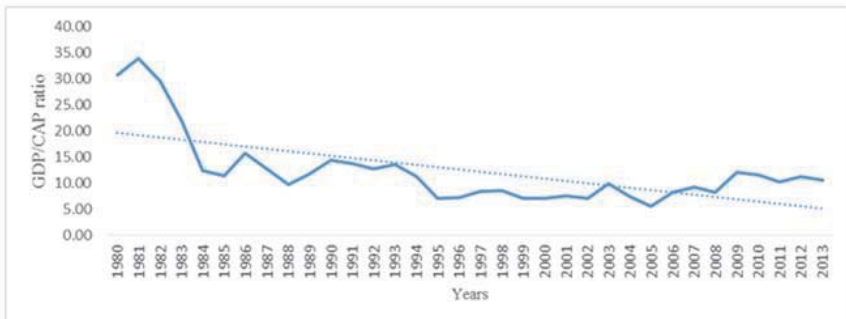

Figure 3: Trend of GDP/CAP Ratio, 1980-2013 


\section{Literature Review}

External debt is defined as a financial commitment that link one party, the debtor country to another, the lender country; it mostly denotes incurred debt which are repayable in denominations other than the debtor nation's currency (Ajab \& Audu, 2006). The major consideration at the time of going into contract for a foreign loan is that one should take cognizance of the fact that profit on investment is by far more than the cost of borrowing. Ajayi and Khan (2000) opined that by this consideration the borrower will be raising capacity and growing productivity using foreign savings through external debt (McKinnon, 1964).

The abundance and availability of low priced international loans in 1970s lead to the proliferation of external debts among the third world countries (Ajab \& Audu, 2006). This was in addition to lack of domestic savings, high current account deficit, sharp decline in terms of trade and the crude oil price changes in 1973/74 and 1978/79 plus the rise in public spending of especially SSA countries as a result of increases in the prices of imports during the early 1970s. These contributed immensely in developing countries opting for importation of capital to augment domestic resources (Were, 2001; Suma, 2007). External debt is therefore considered common occurrence for developing nations in their initial stage of development aiming at smoothing and boosting their capital formation process which is a sine qua non to investment in particular and economic growth in general (Chenery \& Strout, 1966).

The work of Were (2001) observed that the capacity of the difference between consumption and income in underdeveloped economies has not been high enough due to the inadequacy of income and should therefore be augmented with external funds to enhance investment that will lead to improvement in economic growth and development. It should be born in mind however, that this will happen only when such funds are efficiently invested and profitably utilized. This will lead to an improvement in the rate of growth of GDP and will have the capacity of servicing its outstanding commitments. Significant contribution to economic growth is expected from foreign debts as has been the results in many developing countries where the reason for incessant dearth of capital mostly originates from inadequate inflow from outside their economies in form of foreign exchange (Ajab \& Audu, 2006). All these are aimed at improving the position of capital formation considered a necessity for a sustainable economic growth.

Generally, the idea of a financing gap theory which is an offshoot of the dual gap theory has infested the developing countries with the opening of the floodgates for the so called foreign borrowings. Financing gap is essentially the difference between funds that are available from domestic sources and total investment requirement; and one way of closing this gap is by borrowing from abroad. Domar's model postulated that there would be a proportionate relationship between investment, spending and the total growth of GDP. In the same vain the financing gap idea appeared in the work of Rostow (1960), Rostow deduced that the necessary condition for take-off is that investment increases from five to 10 percent of profits which means that if a developing country does not have enough domestic resources for investment it must fill the gap with foreign aid or external debt.

\section{Methodology}

\subsection{Sources of Data}

Yearly time series data on capital formation, external debt, savings, external debt service and interest rate for the 1980 to 2013 period were adopted for the purpose of this analysis. The data were sourced from a World Bank publication and the World Development Indicators.

\subsection{Model Specification}

The dual gap theory was propounded on the premise that internal resources in form of national savings is insufficient to drive the third world countries economic developmental needs hence their resorting to foreign funding. The dual gap theory asserts that savings determines investment which is a sin-qua-non for economic growth; but that domestic savings is not enough to sustain economic growth (Chenery \& Strout, 1966). On the basis of the fore going therefore and in line with the objective of the study an econometric model of capital formation as in Equation [1] is developed. For the purpose of the analysis, the model captures capital formation $(C A P)$ as the dependent variable while total external debt $(E X D)$, external debt service (EDS), interest rate (INT) and national savings (SAV) represent the explanatory variables.

[1] $\ln C A P_{t}=\delta_{0}+\delta_{1} \ln E D S_{t}+\delta_{2} \ln E X D_{t}+\delta_{3} \ln I N R_{t}+\delta_{4} \ln S A V_{t}+\mu_{t}$

where $\delta_{0}$ is the intercept, $\delta_{1}-\delta_{4}$ are the coefficients of external debt service, total external debt stock, interest rate, 
and national savings, respectively and, ${ }_{t}$ is the error term assumed to be identically independently distributed.

\subsection{Stationarity test}

Stationarity test is preliminary to the analyses of time series data as well as being imperative for proper modeling in addition to having important economic interpretations. The characteristic of time series data as non-stationary has been generally seen as a problem in empirical analysis (Nelson \& Plosser, 1982). It is also generally agreed that using data series that are non-stationary may lead to results that are unreliable which, may in addition give worthless inferences. Thus, the examining effects of one variable on another requires the determination of whether the variables (or series) are stationary at level, I(0) or at first difference, I(1). Even though this work intends to adopt the Autoregressive Distributed Lag (ARDL) framework which does not necessarily require that variables be tested for unit root, testing for the order of integration could be helpful in determining whether ARDL approach is suitable or not (Sulaiman \& Abdul-rahim, 2013). The ARDL framework developed by Pesaran, Shin, and Smith (2001), was based on the assumption that all the variables in the model are either I(0), I(1) or mixture of both. Any presence of I(2) variable in the model will render the methodology invalid. As such, Stationarity test is required to identify the true order of integration of the respective variables in the model.

Stationarity of the variables or otherwise is determined by applying the unit root tests of the Augmented DickeyFuller (ADF) test. An ADF test examines whether a time series data has a unit root problem otherwise known as nonstationary or not. It was developed by Dickey and Fuller in 1976 and subsequently by Dickey and Fuller $(1979,1981)$ which resulted into the Dickey Fuller-test (DF-test). DF-test is a one-sided test because of the alternative proposition or hypothesis that $\delta<0$ (or $\rho<1$ ). Stationary series should have zero means and constant variance. The null hypothesis, $\mathrm{H}_{0}$ : $\delta=0$ (i.e. the data is non-stationary or there is a unit root problem) and the alternative hypothesis, $\mathrm{H} 0: \delta<0$ (i.e. the data is stationary or there is no unit root).

\subsection{The ARDL Bounds Test}

With a successful determination of levels of integration of the variables, then the likelihood of long run association between capital formation and other independent variables using the ARDL bounds test as proposed by Pesaran and Shin (1999) and extended by Pesaran et al. (2001). The ARDL test has many advantages over and above the other methods. It employs a single reduced form equation, as against other cointegration methods, which require laborious system of equation to estimate long run relationship. ARDL bound test is applicable irrespective of whether the series are I(0), I(1) or a mixture of both. An additional advantage of the ARDL is that, the long and short-run factors of the model are assessed at the same time. Thus the difficulty in testing the hypotheses on the estimated coefficients in the long run as observed in the Engle-Granger method is avoided while it accommodates small sample series (Narayan, 2005).

The long run relationship among the variables would therefore be examined using ARDL unrestricted error correction model developed by Pesaran et al. (2001) as per Equation [2].

[2]

$\Delta \ln C A P_{t}=\delta_{0}+\sum_{i=1}^{t} \xi_{i} \Delta \ln C A P_{t-i}+\sum_{i=0}^{t} \vartheta_{i} \Delta \ln E D S_{t-i}+\sum_{i=0}^{t} \Omega_{i} \Delta \ln E X D_{t-i}+\sum_{i=0}^{t} v_{i} \Delta I N T_{t-i}$

$$
+\sum_{i=0}^{t} \rho_{i} \Delta \ln S A V_{t-i}+\Psi_{1} \ln C A P_{t-1}+\Psi_{2} \ln E D S_{t-1}+\Psi_{3} \ln E X D_{t-1}+\Psi_{4} \ln I N T_{t-1}+\Psi_{5} \ln S A V_{t-1}+\eta_{t}
$$

where the symbol $\Delta$ is the difference operator, $\ln C A P_{t} \ln E D S_{t}, \ln E X D_{t}, \ln S A V_{t}$ and $\ln I N T_{t}$ denote natural logs of capital formation, external debt service, external debt stock, national savings and interest rate respectively. The long run relationship is determined using $F$-statistics to test the significance of the one lagged level variables. The joint significance of the model to be tested are $H_{0}: \Psi_{1}=\Psi_{2}=\Psi_{3}=\Psi_{4}=\Psi_{5}=0$ and $H_{1}: \Psi_{1} \neq \Psi_{2} \neq \Psi_{3} \neq \Psi_{4} \neq \Psi_{5} \neq 0$.

The critical values of Narayan (2005) were used for purely level variables I(0), purely differenced variables I(1) and mutually cointegrated variables. The ARDL unrestricted error correction models (UECM) will be projected as in Equation [2]. In order to establish the existence of cointegration amongst the variables the value of calculated F-statistics is placed against the two critical values of lower and upper bounds as in Narayan (2005). These critical values represent lower and upper bounds limits for I(0) and I(1) variables respectively. The bound test decision entails that, there is cointegration when computed $F$-statistic surpasses the upper critical value. If the F-statistic drops in between the two bounds of critical values, the test is considered inconclusive while, there is no cointegration when the F-statistic is less than the lower critical value (Narayan, 2005). 


\section{The Long Run relationships}

The long run elasticities of the model are estimated based on the following ARDL model to investigate the effects of the independents variables on the left hand side variable in the long run. In other words Equation [3] is estimated for the purpose of determining the values of the coefficient of the independent variables in the long run.

[3] $\ln C A P_{t}=\delta_{1}+\sum_{i=1}^{l} \xi_{1 i} \ln C A P_{t-i}+\sum_{i=0}^{l} \vartheta_{1 i} \ln E D S_{t-i}+\sum_{i=0}^{l} \Omega_{1 i} \ln E X D_{t-i}+\sum_{i=0}^{l} v_{1 i} I N T_{t-i}+\sum_{i=0}^{l} \rho_{1 i} \ln S A V_{t-i}+\eta_{1 t}$

\subsection{The Short Run Relationships}

The short run elasticities are estimated using ARDL error correction model (ECM) of the following order as in Equation [4].

$$
\begin{aligned}
& \quad \Delta \ln C A P_{t}=\delta_{2}+\sum_{i=1}^{l} \xi_{2 i} \Delta \ln C A P_{t-i}+\sum_{i=0}^{l} \vartheta_{2 i} \Delta \ln E D S_{t-i}+\sum_{i=0}^{t} \Omega_{2 i} \Delta \ln E X D_{t-i}+\sum_{i=0}^{t} v_{2 i} \Delta I N T_{t-i} \\
& +\sum_{i=0}^{l} \rho_{2 i} \Delta \ln S A V_{t-i}+\psi E C T_{t-1}+\eta_{2 t}
\end{aligned}
$$

where $E C T_{t-1}$ represents error correction term which measures the effectiveness of the feedback or adjustment mechanism in stabilizing disequilibrium in the model. In other words, it describes how disequilibrium in the model will instantaneously converge to equilibrium after a given shock in the economy. Furthermore, a negative significant coefficient of the $E C T$ term is required to ensure the existence of long run relationship and adjustment of disequilibrium in the model (Narayan, 2005). The higher the magnitude of the ECT term the better will be the speed of adjustment (Coakley, Fuertes, \& Spagnolo, 2004).

\section{Discussions of Empirical Results}

Table 2 exhibits the results of the ADF Stationarity test. A major assumption of the test is that the series are independently and identically distributed. The results indicates that the variable of $\ln E D S$ and $\ln$ EXD are stationary at first difference I(1). Variables of In INT, In SAV and In CAP are stationary at level I(0). The model has thus satisfied the basic condition under which ARDL can be applicable.

Table 2: The Augmented Dickey Fuller Stationarity Test Results

\begin{tabular}{lcccc}
\hline \multirow{2}{*}{ Variables } & \multicolumn{2}{c}{ Constant Without Trend } & \multicolumn{2}{c}{ Constant With Trend } \\
\cline { 2 - 5 } InEDS & $-1.64(0)$ & First Difference & \multicolumn{1}{c}{ Level } & First Difference \\
InEXD & $-1.25(1)$ & $-4.81(0)^{*}$ & $-2.57(0)$ & $-4.79(0)^{*}$ \\
InCAP & $-3.55(3)^{*}$ & $-5.11(1)^{*}$ & $-2.21(0)$ & $-5.54(0)^{*}$ \\
$\ln / N R$ & $-3.87(1)^{*}$ & $-3.79(2)^{*}$ & $-2.83(3)$ & $-6.24(1)^{*}$ \\
InSAV & $-4.07(0)^{*}$ & $-8.45(0)^{*}$ & $-5.88(1)^{*}$ & $-3.68(2)^{*}$ \\
\hline Note: Figures are the $t$-statistics for testing the null hypothesis that the series is non-stationary. \\
* denotes significance at 5\% level. \\
Figures in parentheses are lag lengths.
\end{tabular}

Table 3, on the other hand, explains the outcome of the ARDL bound cointegration test. All the variables show a statistically significant level of long run relationship at 5 percent level of significance with the exception of EDS which fell below the lower critical bounds limit. This indicates that external debt, interest rate and national savings have long run relationships when each of them is made a dependent variable. Thus, the condition of cointegration has been fulfilled to enable further estimation using the ARDL method. 
Table 3: The Result of the ARDL Bound Test

\begin{tabular}{|c|c|c|c|c|c|}
\hline \multirow[t]{2}{*}{ Dependent Variables } & \multirow{2}{*}{$\begin{array}{l}\text { Calculated } \\
\text { F-statistics }\end{array}$} & \multirow{2}{*}{$\begin{array}{l}\text { Lag } \\
\text { Length }\end{array}$} & \multirow[t]{2}{*}{ Level of sig. } & \multicolumn{2}{|c|}{$\begin{array}{l}\text { Bounds test critical values unrestricted } \\
\text { intercept and restricted trend }\end{array}$} \\
\hline & & & & $\mathrm{I}(0)$ & $\mathrm{I}(1)$ \\
\hline $\ln C A P$ & $6.250^{*}$ & 2 & $1 \%$ & 4.779 & 6.821 \\
\hline $\ln E X D$ & $18.747^{\star}$ & 3 & & & \\
\hline $\ln E D S$ & 1.743 & 3 & $5 \%$ & 3.394 & 4.939 \\
\hline $\ln / N T$ & $10.358 *$ & 3 & $10 \%$ & 2.843 & 4.160 \\
\hline InSAV & $37.024^{*}$ & 3 & & & \\
\hline
\end{tabular}

Note: Based on Narayan (2005) critical bounds values table case IV.

* denotes significance at $5 \%$ level.

The bold signifies that at $5 \%$ significance level of the critical bounds values, the F-statistics is greater than the upper bound values which means that presence of strong cointegration relation.

The optimum ARDL model is estimated via the optimum model selection criteria as in Table 4. The selected ARDL in this case is ARDL $(2,0,2,0,1)$ based on the Schwarz Bayesian Criterion (SBC). Meanwhile, Table 5 shows that total external debt stock and external debt service have some mild, negative and statistically significant long term relationships. This has gone to confirm the findings of Adegbite, Ayadi, and Ayadi (2008) and Siddique, Selvanathan, and Selvanathan (2015). The impact of savings on capital formation has been established to be positive in the long run with a coefficient of 0.174 and $p$-value of 0.006 depicting a very strong statistical significance. In fact all the variables have shown very strong statistical significance except for interest rate that has shown a weak statistical significance.

Table 4: Optimal ARDL $(2,0,2,0,1)$ Estimates Results

Dependent Variable is InCAP

\begin{tabular}{lcccc}
\hline Variables & Coefficient & Standard Error & t-statistics & $p$-values \\
\hline $\operatorname{In} C A P(-1)$ & 0.447 & 0.160 & 2.791 & $0.011^{*}$ \\
$\operatorname{In} C A P(-2)$ & -0.341 & 0.173 & -1.966 & $0.063^{* *}$ \\
$\operatorname{In} E X D$ & -0.199 & 0.087 & -2.289 & $0.033^{*}$ \\
$\operatorname{In} E D S$ & 0.000 & 0.000 & -2.295 & $0.032^{*}$ \\
$\operatorname{In} E D S(-1)$ & 0.000 & 0.000 & 0.683 & 0.502 \\
$\operatorname{In} E D S(-2)$ & 0.000 & 0.000 & -2.706 & $0.013^{*}$ \\
$\operatorname{In} / N R$ & -0.037 & 0.020 & -1.849 & $0.079^{* *}$ \\
InSAV & 0.011 & 0.046 & 0.240 & 0.812 \\
$\operatorname{InSAV}(-1)$ & 0.145 & 0.044 & 3.254 & $0.004^{*}$ \\
$C$ & 4.595 & 3.028 & 1.518 & 0.144 \\
$T$ & -0.049 & 0.013 & -3.932 & $0.001^{*}$ \\
\hline Note: ${ }^{*}$ and ${ }^{* *}$ signify $5 \%$ and $10 \%$ level of significance accordingly. &
\end{tabular}

Table 5: Estimations of the Long Run Relationships, ARDL $(2,0,2,0,1)$

\begin{tabular}{lcccc}
\multicolumn{5}{c}{ Dependent Variable InCAP } \\
\hline Variable & Coefficient & Standard Error & t-statistic & $p$-value \\
\hline $\operatorname{In} E X D$ & -0.223 & 0.084 & -2.664 & $0.015^{*}$ \\
InEDS & -0.101 & 0.000 & -3.520 & $0.002^{*}$ \\
InINT & -0.042 & 0.022 & -1.908 & $0.070^{* *}$ \\
InLSAV & 0.174 & 0.057 & 3.071 & $0.006^{*}$ \\
$C$ & 5.143 & 3.153 & 1.631 & 0.118 \\
$T$ & -0.055 & -0.008 & -7.286 & $0.000^{*}$ \\
\hline Note: * and ** signify 5 \% and 10 \% level of significance accordingly.
\end{tabular}

The short run relationships of the ARDL model is given in Table 6. The results suggest that the external debt variable has a moderate negative relationship on capital formation of about 20 percent in the short run, followed by the external debt service and savings both with a positive and negatives signs respectively and as expected. Interest rate is shown to have had the least effect on capital formation in the short run. The coefficient of the $E C T_{t-1}$ is negative as defined by theory and the speed of adjustment is at 89 percent; very strong and statistically significant at both one and five percent significance 
levels.

The coefficient of $E C T_{t-1}$ term has the expected sign and statistically significant at one percent. It endorses the existence of association between the dependent and explanatory variables in the long run. The coefficient of the ECT $T_{t-1}$ suggests a very fast adjustment process with 89 percent of the previous year's disequilibrium in capital formation adjusted in the current year. Thus, the suggestion is that capital formation in Nigeria is primarily guided by the components of external debt and external debt service, interest rate and national savings.

Table 6: Estimated Short Run Coefficients, $\operatorname{ARDL}(2,0,2,0,1)$

\begin{tabular}{|c|c|c|c|c|}
\hline \multicolumn{5}{|c|}{ Dependant variable is dlnCAP } \\
\hline Variables & Coefficient & Standard Error & $t$-statistic & $p$-value \\
\hline $\operatorname{dnn} C A P_{t-1}$ & 0.341 & 0.173 & 1.966 & $0.061^{\star \star}$ \\
\hline $\operatorname{dn} E X D$ & -0.199 & 0.087 & -2.289 & $0.032^{\star}$ \\
\hline dlnEDS & 0.000 & 0.000 & -2.295 & $0.031^{*}$ \\
\hline $\operatorname{dn} E D S_{t-1}$ & 0.000 & 0.000 & 2.706 & $0.013^{*}$ \\
\hline $\mathrm{d} \ln / N R$ & -0.037 & 0.020 & -1.849 & $0.077^{* *}$ \\
\hline dlnSAV & 0.011 & 0.046 & 0.240 & 0.812 \\
\hline$d C$ & 4.595 & 3.028 & 1.518 & 0.143 \\
\hline $\mathrm{d} T$ & -0.049 & 0.013 & -3.932 & $0.001^{*}$ \\
\hline$E C T_{t-1}$ & -0.894 & 0.169 & -5.285 & $0.000^{*}$ \\
\hline
\end{tabular}

Note: ${ }^{*}$ and ${ }^{* *}$ signify $5 \%$ and $10 \%$ level of significance accordingly.

\subsection{The Granger Causality Test}

Granger causality between $\operatorname{InCAP}, \ln E X D, \ln E D S$, InINR and InSAV have been considered in order to see the direction of causality and which of the variables Granger causes the other in Table 7.

Table 7: The ARDL Granger Causality Test Result

\begin{tabular}{llcl}
\hline Null hypothesis & F-statistics & p-values & Conclusion \\
\hline InEXD does not Granger cause InCAP & 6.530 & $0.019^{\star}$ & Unidirectional Causality \\
InCAP does not Granger cause InEXD & 0.024 & 0.877 & \\
InEDS does not Granger cause InCAP & 0.224 & 0.636 & Unidirectional Causality \\
InCAP does not Granger cause InEDS & 6.194 & $0.013^{\star}$ & \\
In/NT does not Granger cause InCAP & 3.815 & $0.051^{*}$ & Bidirectional Causality \\
InCAP does not Granger cause InINT & 5.740 & $0.017^{*}$ & \\
InSAV does not Granger cause InCAP & 0.062 & 0.803 & Unidirectional Casualty \\
InCAP does not Granger cause InSAV & 5.640 & $0.027^{*}$ & \\
\hline
\end{tabular}

Note: * and ${ }^{* \star}$ signify $5 \%$ and $10 \%$ level of significance accordingly.

From Table 7, it can be understood that the "null hypothesis" that InEXD does not Granger cause $\ln C A P$ is rejected at 5 percent significance level while the null hypothesis that $\operatorname{InEDS}$ does not Granger cause InCAP was also rejected at the same level of significance. On the other hand, InINT and InCAP were found to have two ways causation at 5 and 10 percent levels of significance, respectively. The analysis also confirmed one way causation between InCAP and InSAV. The policy implication of this findings is that government should give more emphasis on controlling interest rates and external debt services while strongly encouraging savings in the economy. It is also indicative to say that policies by government on external debt and external debt service can affect capital formation but policies or actions on capital formation cannot in any way affect them. On the other hand, policies on either savings or capital formation in the country affect one another.

\subsection{Diagnostic Tests}

Applying series of analytical reviews in form of diagnostic tests to the ARDL models and estimates, the serial correlation analyses indicated no sign of autocorrelation. The Ramsey Reset test for functionality defines the model has been well specified and functionally formed and fitted. Moreover, heteroscedasticity tests based on regression of squared residuals on squared fitted values show that errors are homoscedasticity and independent of the regressors (Table 8). Given that 
Cumulative sum of squares of recursive residuals and the Cumulative sum of recursive residuals test statistics plotted lines do not exceed the bounds of the 5 percent level of significance in Figures 4 and Figure 5 makes the ARDL estimated model stable (Durbin, 1975).

Table 8: The Diagnostic Test Results

\begin{tabular}{llc}
\hline Test Statistics & LM Statistics & F-statistics \\
\hline A:Serial Correlation & CHSQ $(1)=1.085[0.298]$ & $\mathrm{F}(1,20)=0.702[0.412]$ \\
B:Functional Form & CHSQ $(1)=5.479[0.019]$ & $\mathrm{F}(1,20)=4.132[0.056]$ \\
C:Normality & CHSQ $(2)=0.086[0.958]$ & Not applicable \\
D:Heteroscedasticity & CHSQ $(1)=0.008[0.927]$ & $\mathrm{F}(1,30)=0.008[0.930]$ \\
\hline
\end{tabular}

Note: A:Lagrange multiplier test of residual serial correlation

B:Ramsey's RESET test using the square of the fitted values

C:Based on a test of skewness and kurtosis of residuals

D:Based on the regression of squared residuals on squared fitted values

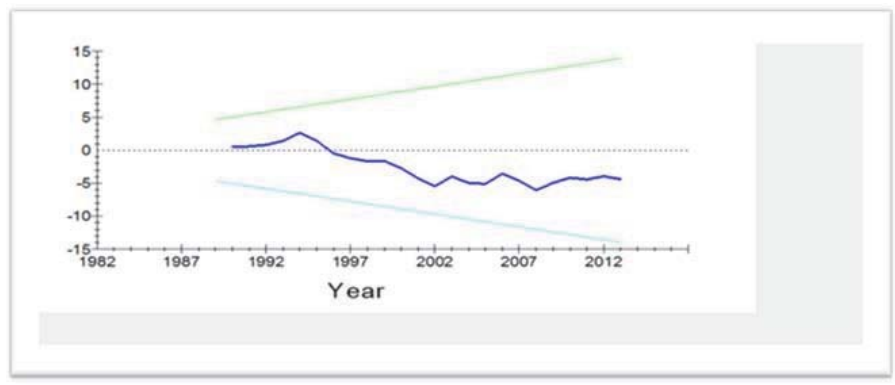

Figure 4: Plot of Cumulative Sum of Recursive Residuals

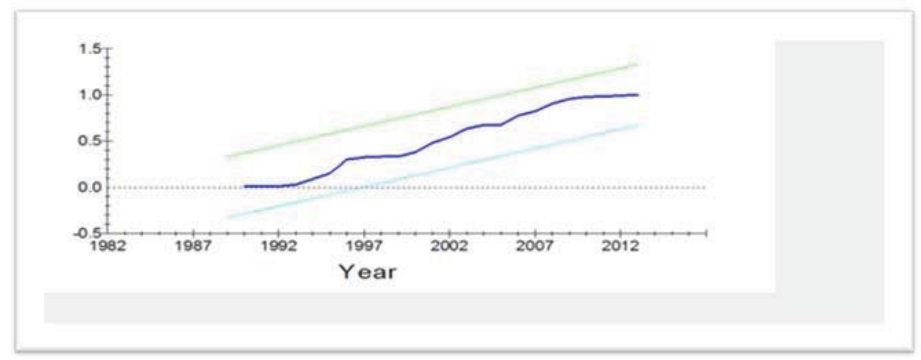

Figure 5: Plot of Cumulative Sum of Squares of Recursive Residuals

\section{Summary of Findings, Policy Implications and Conclusions}

The purpose of this paper is to examine the short and long run relationships between external debt and capital formation in Nigeria using ARDL bound test approach. Time series data for a period of 34 years from 1980 to 2013 were utilized for the purpose of the estimations. The result of stationarity tests reported a mixed integration at both I(0) and I(1) levels. The ARDL bonds test confirmed the variables cointegration otherwise known as the existent of a long run relationship amongst the variables. It was also further proved by the long run outcomes of estimation that the variables were independently related. The impact of savings on capital formation has been established to be positive but not statistically significant, while interest rate was also shown to be statistically significant even though weak. Thus, it was evident that capital formation in Nigeria is mainly determined by the components of external debt and external debt services interest rate and national savings

The $E C T_{t-1}$ measured the effectiveness of the feedback or adjustment mechanism in stabilizing disequilibrium in 
the model. In other words, it described how disequilibrium in the model will instantaneously converge to equilibrium after a given shock in the economy. The short-run dynamics of the relationship between the variables were examined using ARDL. ECM indicated that the disequilibrium in the previous period will be adjusted within the current period by 89 percent, showing a speedy adjustment rate. The coefficient of ECT has the expected sign and significant at one percent. In addition further diagnostic tests confirmed that there was no indication of autocorrelation of the error terms in the ARDL estimators; thus model used is considered highly stable.

The impact of external debt on capital formation has appeared negative and statistically significant. External debt should therefore be utilized for essential purposes. The economic policies should be directed at raising competitiveness by improving macroeconomics imbalances and marshalling national assets in order to fill in the investment or savings gap created by under savings and thus reducing the countries dependence on external debt. An improved debt management should thus take cognizance of the conditionality guiding the borrowed funds, and the economy will be in a position to shoulder debt services burden of the facilities.

The existence of a negative long run relationship between external debt and capital formation in Nigeria indicates that increase in external debt could negatively affect capital formation. At the same time, there is a short run relationship between external debt and capital formation. This indicates that, an increase in external debt leads to a decrease in capital formation in the short run. There thus exists a strong need to provide a favorable macroeconomic environment targeted towards reducing mismanagement so as to promote economic activities that will lead to improvement in capital formation.

It is also pertinent to observe that since external debt granger causes capital formation it means that any policy in favor of external debt by the government will have resultant effects on capital formation while actions or inactions on capital formation will not have serious consequences on external debt. On the other hand however government should encourage the culture of savings given that any policy change on savings goes a long way in affecting capital formation.

\section{References}

Adegbite, E. O., Ayadi, F. S. \& Felix A, O. (2008). The impact of Nigeria's external debt on economic development. International Journal of Emerging Markets, 3(3), 285-301.

Ajab, A. A. \& Audu, I. (2006). External debt, investment and economic growth: Evidence from Nigeria. Central Bank of Nigeria: Economic and Financial Review, 44(1), 81-113.

Ajayi, S. I. \& Khan, M. S. (2000). External debt and capital flight in Sub-Saharan Africa. Washington D.C.: International Monetary Fund Institute.

Aliyu, R. M. \& Usman, U. A. (2013). An econometric study of the impact of external debt, public debt and debt servicing on national savings in Nigeria: A cointegration approach. International Journal of Management and Social Research, 2(2), 2319-4421.

Chenery, H.B. \& Strout, A. (1966). Foreign assistance and economic development. American Economic Review, 56(4), 678-733.

Coakley, J., Fuertes, A. M. \& Spagnolo, F. (2004). Is the Feldstein-Horioka Puzzle history? The Manchester School, 72, 569-590.

Dickey D.A. \& Fullerm, W. A. (1979). Distribution of the estimators for autoregressive time series with a unit root. Journal of the American Statistical Association, 74, 427-431.

Dickey, D. A. \& Fuller, W. A. (1981). Likelihood ratio statistics for autoregressive time series with a unit root. Econometrica, 49, 10571072.

Gillis, M., Perkins, D. W., Roemer, M. \& Snodgrass, D. R. (1987). Economics of Development. Second Edition, New York: W.W. Norton. Hernández-Catá, E. (2000). Raising growth and investment in Sub-Saharan Africa: What can be done? Finance and Development, 37(4), 1-27.

Hunt, S. D. (2007). Economic growth: Should policy focus on investment or dynamic competition? European Business Review, 19(4), 279-91

J. Durbin, J. M. E. R. L. B. (1975). Techniques for Testing the Constancy of Regression Relationships over Time. Journal of the Royal Statistical Society, 37(2), 149-192.

Jhinghan, M. L. (2003). Advanced economic theory (Micro and Macro). 12 ${ }^{\text {th }}$ Edition, New Delhi: Vrinda Publications.

McKinnon, R. (1964). Foreign exchange constraints in economic development and efficient aid allocation. The Economic Journal, 74(294), 388-409.

Narayan, P. K. \& Narayan, S. (2005) Estimating income and price elasticities of imports for Fiji in a cointegration framework, Economic Modelling, 22(3), $423-438$.

Narayan, P. K. (2005). The saving and investment nexus for China: Evidence from cointegration tests. Applied Economics, 37(17), 1979-1990.

Nelson, C. R. \& Plosser, C. I. (1982). Trends and random walks in macro-economic time series. Journal of Monetary Economics, 10, 139-62.

Nigeria, Federal Republic (2015), 2014 Annual reports and statement of accounts, Nigeria: The Debt Management Office.

Nurkse, R. (1966). Problems of capital formation in underdeveloped countries. Oxford: Basil Blackwell. 
Omotoye, R. O., Sharma, H. P., Ngassam, C. \& Eseonu, M. (2006). Sub-Saharan Africa's debt crisis: Analysis and forecast based on Nigeria. Managerial Finance, 32(7), 606-620.

Pesaran, M. H., Shin, Y. \& Smith, R. J. (2001). Bounds testing approaches to the analysis of level relationships. Journal of Applied Econometrics, 16, 289-326.

Pesaran, M.H. \& Shin, Y. (1999). An autoregressive distributed lag modelling approach to cointegration analysis. In Strom, S. (Ed.). Econometrics and economic theory in the 20th century: The Ragnar Frisch Centennial Symposium. Cambridge: Cambridge University Press. (Chapter 11).

Rostow, W. W. (1960). The stages of economic growth: A non-communist manifesto. Third Editions, New York: Harper and Row.

Sachs, J. (2002). Resolving the debt crisis of low-income countries. Brookings Papers on Economic Activity, 2002(1), 257-286.

Siddique, A., Selvanathan, E. A. \& Selvanathan, S. (2015). The impact of external debt on economic growth : Empirical evidence from highly indebted poor countries. Griffith Business School, Griffith University. 1-31.

Sulaiman L.A. \& Azeez, B. A. (2012). Effect of external debt on economic growth of Nigeria. Journal of Economics and Sustainable Development, 3(8), 71-80.

Sulaiman, C. \& Abdul-rahim, A. S. (2013). The short- and long-run effects of sustainable forest management practices on trade in Thailand's forest products. Global Conference on Business and Economics Research (GCBER 2013), 103-113. University Putra Malaysia, Malaysia.

Were, M. (2001). Impact of external debt on economic growth and private, investments in Kenya: An empirical assessment. Wider Development Conference on Debt Relief, 17-18 August 2001, Helsinki. 